4

\title{
Strategi Kemitraan Agribisnis Berkelanjutan ${ }^{1)}$
}

\author{
Ninuk Purnaningsih"),
}

\section{Ringkasan}

Penerapan pola kemitraan agribisnis bertujuan untuk mengatasi masalah-masalah keterbatasan modal dan teknologi bagi petani kecil, peningkatan mutu produk, dan masalah pemasaran. Namun pada kenyataannya penerapan kemitraan tersebut sering menghadapi masalah, baik yang bersumber dari petani mitra maupun dari pihak perusahaan yang menyebabkan kemitraan yang dibangun tidak dapat berkelanjutan. Melihat potensi dan tantangan penerapan pola kemitraan sebagai suatu inovasi dalam peningkatan kinerja petani kecil, maka penting menganalisis faktorfaktor yang mempengaruhinya penerapan pola kemitraan agribisnis dan merumuskan strategi kemitraan yang berkelanjutan. Penelitian ini menggunakan metode studi kasus di lima perusahaan agribisnis dan satu koperasi yang menerapkan pola kemitraan agribisnis di Jawa Barat: Bogor, Cianjur, Bandung, dan Garut. Populasi penelitian adalah petani di sekitar perusahaan dan koperasi, dengan unit analisis rumahtangga tani.

Sejak akhir tahun 90 hingga sekarang (2006) bisnis sayuran menjadi semakin banyak diminati oleh masyarakat. Namun dari banyak perusahaan agribisnis di Jawa Barat yang mencoba menerapkan pola kemitraan agribisnis dengan petani sekitar hanya beberapa perusahaan saja yang mampu bertahan. Secara umum petani berhenti bermitra karena beberapa alasan.

Adapun terkait dengan strategi penerapan pola kemitraan agribisnis antara petani dan perusahaan, koperasi dan pedagang pengumpul tersebut, sebaiknya dilakukan dengan berbagai cara. Dalam rangka mencapai mutu produk sesuai kebutuhan konsumen, spesialisasi kegiatan untuk efisiensi, dan wadah kerjasama pemerintah dan swasta dalam penyelenggaraan penyuluhan pertanian.

Katakunci: adopsi, kemitraan, agribisnis, sayuran

\section{Pengantar}

Dalam rangka pembangunan pertanian dengan konsep agribisnis, pemerintah mengeluarkan UU No. 9 tahun 1995 tentang Usaha Kecil yang kemudian dijabarkan pada PP No 44 tahun tahun 1997 tentang Kemitraan. Aturan tersebut antara lain ditujukan untuk mengatasi masalah-masalah keterbatasan modal dan teknologi bagi petani kecil, peningkatan mutu produk, dan masalah pemasaran. (Departemen Pertanian, 2003). Di sektor tanaman pangan dan hortikultura, sayuran merupakan sektor yang banyak diminati untuk

1) Merupakan sebagian analisis dari disertasi penulis pada Program S3 Sekolah Pascasarjana IPB

2) Staf Pengajar Departemen Komunikasi dan Pengembangan Masyarakat, Fakultas Ekologi Manusia Institut Pertanian Bogor 
dikembangkan melalui kemitraan karena siklusnya yang pendek, dan potensi pasarnya yang tinggi.

Konsep kemitraan mengacu pada konsep kerjasama antara usaha kecil dengan usaha menengah atau usaha besar disertai pembinaan, dengan memperhatikan prinsisp saling menguntungkan dan memperkuat. Pola kemitraan adalah bentuk-bentuk kerjasama antara usaha kecil dan usaha menengah atau usaha besar. Pola kemitraan sebagai suatu inovasi mengandung pengertian bahwa telah terjadi proses pembaharuan (inovasi=sesuatu yang baru) terhadap pola kemitraan dalam banyak hal. Artinya pola kemitraan bukan sesuatu yang baru sama sekali di dunia petani, tetapi telah mengalami proses perubahan dari waktu ke waktu hingga saat ini.

Proses kerjasama antar petani, antara petani dengan pedagang pengumpul, dan antara petani dengan kios saprodi telah terjadi sejak lama. Proses kerjasama tersebut yang kemudian disebut sebagai proses bermitra. Pada awalnya, proses tersebut berlangsung tanpa ada sesuatu aturan formal, semua didasari oleh rasa percaya antar pelaku. Wilayah yang terbatas dalam suasana interaksi yang intensif, saling kenal dengan baik satu sama lain, membuat proses bermitra berjalan dengan kontrol sosial antar pelaku.

Seiring dengan berkembangnya ilmu pengetahuan dan teknologi, bertambahnya jumlah pelaku bisnis sayuran, dan wilayah kerjasama yang semakin luas, maka proses kerjasama tersebut pun berkembang. Perkembangan inovasi pola kemitraan tersebut berbeda-beda sesuai dengan kondisi masyarakatnya, atau sesuai dengan kultur dan struktur masyarakatnya. Bila dilihat dari sisi pengorganisasian kegiatan-kegiatan dalam bisnis sayuran, maka pola kemitraan tersebut dapat di kelompokkan pada cara-cara pengorganisasi yang informal yang tradisional sampai cara-cara formal yang modern.

Tulisan ini bertujuan: (1) menganalisis strategi kemitraan yang dapat memberikan manfaat tidak saja bagi petani tetapi juga bagi perusahaan, koperasi dan pedagang pengumpul, sehingga dapat berkelanjutan; (2) mengidentifikan prinsip-prinsip yang harus dilakukan, dan hal-hal yang harus dihindarkan dalam mencapai kemitraan yang berkelanjutan.

Tulisan ini merupakan sebagian analisis yang didasarkan pada data penelitian lapangan tentang penerapan pola kemitraan agribisnis sayuran di Jawa Barat. Penelitian menggunakan metode survei di empat kabupaten di Jawa Barat, yaitu Bogor, Cianjur, Bandung dan Garut, meliputi: 6 perusahaan dan 1 koperasi, serta 285 petani sayuran di mana 57 di antara petani tersebut juga sebagai pedagang pengumpul. Penelitian dilakukan pada bulan Juni 2004 sampai dengan Mei 2005.

\section{Perkembangan Bisnis Sayuran di Jawa Barat}

Jawa Barat merupakan daerah beriklim tropis dengan curah hujan tinggi dan banyak jumlah hari hujan. Keadaan tersebut didukung oleh adanya lahan 
subur berasal dari endapan vulkanis serta banyaknya aliran sungai sehingga menyebabkan sebagian besar dari luas penggunaan tanahnya untuk pertanian. Kondisi topografi daerah utara Jawa Barat merupakan dataran rendah sedangkan daerah selatan berbukit-bukit dengan sedikit pantai serta dataran tinggi bergunung-gunung di sebelah tengah.

Produk pertanian di Jawa Barat antara lain meliputi jenis tanaman pangan, sayur-sayuran dan buah-buahan. Tanaman pangan terdiri dari jenis padipadian, jagung, umbi-umbian, dan kacang-kacangan, sedangkan beberapa jenis sayuran yang dominan antara lain: kentang, kubis, bawang daun, bawang merah, petsai, dan kacang panjang. Secara umum di tahun 2003 areal tanaman pangan di Propinsi Jawa Barat menurun, terutama untuk tanaman ubi, kedelai, kacang hijau dan padi, sedangkan lahan untuk sayuran mengalami peningkatan, terutama untuk kentang, kubis, kembang kol, cabe rawit, dan jamur. Penggunaan lahan untuk pertanian di Jawa Barat tahun 1993 dan 2003 dapat dilihat pada Tabel 1. Secara umum tanpa melihat per jenis tanaman, penggunaan lahan untuk tanaman pangan di tahun 2003 mengalami penurunan sebesar 92,6 persen dibanding tahun 1993, sedangkan luas lahan untuk sayuran mengalami kenaikan delapan kali lebih besar. Secara khusus dengan melihat jenis tanaman sayuran kenaikan luas lahan hanya terjadi pada beberapa komoditas yaitu bawang daun (Allium fistulosum), bawang merah (Allium cepa), kentang (Solanum tuberosum), kubis (Brassica oleracea), wortel (Daucus carota L.) dan jamur yang paling besar.

Tabel 1 Penggunaan Lahan di Jawa Barat Tahun 1993 dan Tahun 2003

\begin{tabular}{|l|l|r|r|r|}
\hline No. & Penggunaan Lahan & $\begin{array}{l}\text { Luas (Ha) } \\
\text { Tahun 1993 }\end{array}$ & $\begin{array}{l}\text { Luas (Ha) } \\
\text { Tahun 2003 }\end{array}$ & $\begin{array}{l}\text { Persen } \\
\text { Perubahan }\end{array}$ \\
\hline 1 & Tanaman Pangan & 48526643 & 3576639 & $-92,6$ \\
\hline 2 & Sayuran & 208878 & 1966240 & 841,3 \\
\hline
\end{tabular}

Sumber : Jawa Barat dalam Angka, 1993 dan 2003

Pada lingkup Indonesia, Propinsi Jawa Barat merupakan salah satu propinsi penghasil sayuran terbesar di Indonesia selain Sumatera Selatan, Sumatera Utara dan Sulawesi Selatan. Hampir semua wilayah di Propinsi Jawa Barat ini merupakan wilayah yang sangat baik dan potensial untuk pengembangan berbagai komoditas pertanian, termasuk sayur-sayuran. Dari 16 kabupaten dan 9 kotamadya yang terdapat di wilayah administratif daerah Jawa Barat, semuanya dapat menghasilkan komoditas pertanian, khususnya komoditas sayuran. Jenis sayuran yang banyak dikembangkan secara komersial di wilayah tersebut antara lain: bawang merah (Allium cepa), bawang putih (Allium sativum), bawang daun (Allium fistulosum), kubis (Brassica oleracea), kentang (Solanum tuberosum), petsai (Brassica rapa L.), wortel (Daucus carota L.), kacang merah (Phaseolus vulgaris), kacang panjang (Vigna unguiculata), cabai (Capsicum annum L.), tomat (Lycopersion esculentum Miller), terung, buncis (Phaseolus 
vulgaris), ketimun (Cucumis sativus L.), labu siam (Sechium edule (fack) sw.), dan bayam (Amaranthus tricolor L.).

Produksi sayuran di Jawa Barat di tahun 2003 meningkat, sedangkan produksi pertanian untuk tanaman pangan mengalami penurunan. Tabel 2 menyajikan total produksi sayuran Jawa Barat pada tahun 2003 adalah sebesar 2,84 juta ton atau mengalami kenaikan sebesar 38,3 persen dari tahun 1993. Sentra penghasil sayuran terbesar di Jawa Barat yaitu, Kabupaten Bandung (34.70\%), dan Kabupaten Garut (22.68\%), Kabupaten Cianjur (10.54\%) dan Kabupaten Bogor (3.47\%) dari produksi total Jawa Barat.

Tabel 2 Jumlah Produksi Sayuran dan Tanaman Pangan (dalam Ton) Tahun 1993 dan Tahun 2003

\begin{tabular}{|l|l|l|l|l|l|l|r|}
\hline No & Lokasi & \multicolumn{3}{|c|}{ Sayuran } & \multicolumn{3}{c|}{ Tanaman Pangan } \\
\cline { 3 - 8 } & & $\begin{array}{l}\text { Tahun } \\
1993\end{array}$ & $\begin{array}{l}\text { Tahun } \\
2003\end{array}$ & $\begin{array}{l}\text { Persen } \\
\text { Perubahan }\end{array}$ & $\begin{array}{l}\text { Tahun } \\
1993\end{array}$ & $\begin{array}{l}\text { Tahun } \\
2003\end{array}$ & $\begin{array}{l}\text { Persen } \\
\text { Perubahan }\end{array}$ \\
\hline 1. & $\begin{array}{l}\text { Jawa } \\
\text { Barat }\end{array}$ & 2060488 & 2849300 & 38,3 & 14100104 & 10818162 & $-23,3$ \\
\hline 2. & Bandung & 518691 & 988758 & 90,6 & 861913 & 830383 & $-3,7$ \\
\hline 3. & Bogor & 100887 & 98771 & $-2,1$ & 755808 & 590402 & $-21,9$ \\
\hline 4. & Cianjur & 254538 & 300296 & 18,0 & 671073 & 688762 & 2,6 \\
\hline 5. & Garut & 337416 & 646238 & 91,5 & 1060264 & 1255485 & 18,4 \\
\hline
\end{tabular}

Sumber: Jawa Barat dalam Angka, Tahun 1993 dan 2003

Kecuali Kabupaten Bogor ketiga kabupaten tersebut di tahun 2003 mengalami kenaikan dalam produksi sayuran di Jawa Barat. Komoditas utama Jawa Barat dan sangat berpengaruh pada produksi total sayuran adalah kubis, kentang, tomat, dan wortel.

Kenaikan produksi sayuran Jawa Barat disisi lain diiringi dengan penurunan jumlah pekerja sektor pertanian, dan penurunan areal tanam pada sebagian besar jenis sayuran, kecuali bawang daun (Allium fistulosum), bawang merah (Allium cepa), kentang (Solanum tuberosum), kubis (Brassica oleracea), wortel (Daucus carota L.) dan jamur (). Dengan demikian dapat disimpulkan bahwa telah terjadi proses intensifikasi pada usahatani sayuran di Jawa Barat selama sepuluh tahun terakhir. 
Tabel 3 Persentase Penduduk yang Bekerja di Sektor Pertanian Tahun 1993 dan Tahun 2003

\begin{tabular}{|l|l|l|l|}
\hline No. & Lokasi & Tahun 1993(Persen) & Tahun 2003 (persen) \\
\hline 1. & Jawa Barat & 37.71 & 34.87 \\
\hline 2. & Bandung & 32.51 & 24.37 \\
\hline 3. & Bogor & 20.59 & 19.09 \\
\hline 4. & Cianjur & 59.48 & 60.63 \\
\hline 5. & Garut & 59.03 & 46.30 \\
\hline
\end{tabular}

Sumber Susenas, 1993 dan Jawa Barat dalam Angka, 2003

Pada tahun 1993 penduduk yang bekerja di sektor pertanian sebesar $37.71 \%$ dan pada tahun 2003 terjadi penurunan menjadi 34.87\%. Persentase penduduk yang bekerja di sektor pertanian dapat dilihat pada Tabel 3. Dari tabel tersebut terlihat bahwa Kabupaten Garut adalah wilayah yang paling banyak terjadi penurunan jumlah pekerja pertanian sekitar 13 persen, sedangkan Cianjur justru mengalami kenaikan sekitar 1 persen.

Perkembangan bisnis sayuran Jawa Barat ditelusuri dari perubahan jenis komoditas pertanian yang diusahakan petani, yaitu dari tanaman pangan ke tanaman sayuran. Tanaman pangan dinilai sebagai tanaman yang menghasilkan bahan makanan pokok, sehingga bertani dapat dikatakan sebagai cara hidup atau cara memenuhi kebutuhan hidup. Berbeda dengan tanaman sayuran, apalagi sayuran dengan nilai ekonomi tinggi, bertani dipandang sebagai cara memperolah keuntungan sebesar-besarnya yang kemudian disebut sebagai bisnis sayuran.

Secara umum petani sayuran Jawa Barat, memulai bisnis sayuran dengan mencoba menanam sayuran lokal sebagai diversifikasi tanaman pangan. Tanaman pangan belum bisa ditinggalkan selagi petani masih merasa tidak aman bila tidak mempunyai persediaan beras, atau palawija. Seiring dengan kemudahan transportasi, maka bahan pangan utama seperti beras dapat dengan mudah dibeli di pasar atau warung. Pada saat itulah petani kemudian mengganti semua tanaman pangan dengan sayuran lokal, seperti wortel, bawang daun, seledri, lobak, kol/kubis, kentang, labu siam, buncis, tomat, kapri, sawi, timun, dll. Sayuran dinilai mempunyai nilai ekonomi yang lebih tinggi dibanding padi dan palawija, karena selain itu siklus tanamnya bervariasi dari yang sangat cepat misalnya 2 minggu sampai 6 atau 8 bulan seperti cabe, juga karena harga jualnya lebih menguntungkan.

Kemajuan di bidang teknologi budidaya dan kemudahan dalam transportasi dan telekomunikasi, mempermudah masuk benih-benih sayuran impor sekaligus merupakan awal bagi bisnis sayuran yang sangat menguntungkan sekaligus juga beresiko tinggi karena membutuhkan modal yang besar. Meskipun ada perbedaan waktu dari satu lokasi ke lokasi yang lain, namun secara umum dapat diperkirakan bahwa perubahan dari tanaman pangan ke sayuran lokal terjadi sekitar tahun 80 -an, sedangkan masuknya benih impor 
sekitar tahun 90-an. Bisnis sayuran menjadi semakin banyak diminati oleh masyarakat sejak akhir tahun 90 hingga sekarang, sebagai alternatif sumber pendapatan bagi para pengangguran korban PHK, pensiunan, dan pemilik modal.

Komoditas unggulan di tiap lokasi berbeda-beda, namun secara umum untuk wilayah Barat dapat diwakili oleh komoditas unggulan enam kabupaten sentra produksi sayuran dan dapat dilihat pada Tabel 4.

Wilayah Bogor yang topografinya berbukit-bukit, dataran tingginya terdapat di sekitar lokasi "wisata puncak" sehingga jenis sayuran yang diproduksi juga bervariasi. Kacang-panjang (Vigna unguiculata) dan ketimun (Cucumis sativus L) .merupakan jenis sayuran dataran rendah sedangkan wortel (Daucus carota L.) dan bawang daun (Allium fistulosum) merupakan sayuran. Kacang panjang dan ketimun merupakan sayuran yang ditanam sebagai upaya diversivikasi jenis tanaman selain menggantikan padi. Kacang panjang dan ketimun merupakan jenis sayuran yang diminati masyarakat sebagai bagian dari menu sehari-hari, sehingga potensi pasarnya cukup baik.

Tabel 4 Jenis Komoditas Unggulan untuk Sayuran Di Jawa Barat

\begin{tabular}{|l|l|l|l|}
\hline No. & Wilayah & $\begin{array}{l}\text { Komoditas Unggulan Tahun } \\
1993\end{array}$ & $\begin{array}{l}\text { Komoditas Unggulan Tahun } \\
2003\end{array}$ \\
\hline 1. & Bogor & $\begin{array}{l}\text { Ketimun,Wortel, Kacang } \\
\text { panjang, Bawang Daun }\end{array}$ & $\begin{array}{l}\text { Kacang Panjang, Ketimun, } \\
\text { Bawang daun }\end{array}$ \\
\hline 2. & Cianjur & $\begin{array}{l}\text { Sawi, Bawang daun, Cabe, } \\
\text { Wortel }\end{array}$ & $\begin{array}{l}\text { Sawi, Wortel, Bawang Daun, } \\
\text { Tomat }\end{array}$ \\
\hline 3. & Bandung & Kubis, Tomat & Kubis, Kentang, Tomat \\
\hline 4. & Garut & $\begin{array}{l}\text { Kentang, cabe, kubis, tomat, } \\
\text { dan wortel }\end{array}$ & Kentang, Tomat, Kubis \\
\hline 5. & Sukabumi & $\begin{array}{l}\text { Petsai/sawi, Ketimun, Tomat, } \\
\text { Kubis }\end{array}$ & $\begin{array}{l}\text { Petsai/sawi, Ketimun, Kacang } \\
\text { panjang, Tomat }\end{array}$ \\
\hline 6. & Kuningan & $\begin{array}{l}\text { Bawang Merah, Bawang } \\
\text { Daun, Kentang, Tomat }\end{array}$ & $\begin{array}{l}\text { Bawang Daun, Bawang Merah, } \\
\text { Kacang Merah, Cabe Rawit }\end{array}$ \\
\hline
\end{tabular}

Sumber: Jawa Barat dalam Angka, 1993 dan 2003

Kabupaten Cianjur terkenal dengan sawi dan wortelnya, bahkan banyak petani di wilayah Cianjur dapat hidup berkecukupan dari hasil menanam wortel. Kabupaten Garut dan Bandung terkenal dengan produksi kentang dan kubisnya, Kabupaten Sukabumi terkenal dengan sawi/petsai, serta Kabupaten Kuningan dengan produksi bawang merah dan bawang daunnya. Keenam kabupaten tersebut merupakan penghasil terbesar sayuran di propinsi Jawa Barat.

Lahan yang diusahakan untuk usahatani sayuran sebagian besar merupakan lahan sawah tadah hujan, pekarangan, dan kebun atau ladang. Secara umum, lahan pertanian di Jawa Barat dapat dibagi menjadi dua macam penggunaan 
lahan yaitu, lahan sawah dan lahan darat. Lahan sawah secara rinci dapat dibedakan menurut jenis pengairan, terdiri dari lahan irigasi teknis, irigasi setengah teknis, irigasi sederhana, tadah hujan, bukan PU, dan lainnya. Lahan darat dibagi lagi menjadi pekarangan, tegal/kebun, ladang/huma, padang rumput, hutan rakyat, hutan negara, rawa-rawa, tambak, kolam dan lain-lain.

\section{Penerapan Pola Kemitraan Agribisnis di Jawa Barat}

Bogor merupakan wilayah yang potensial untuk pengembangan sektor pertanian. Komoditas unggulan untuk Kabupaten Bogor antara lain timun, wortel, kacang panjang, bawang daun. Beberapa Perusahaan Agrisnis di Kabupaten Bogor yang menerapkan pola kemitraan dengan petani dapat dilihat pada Tabel 5.

Tabel 5 Perusahaan Agribisnis di Bogor

\begin{tabular}{|l|l|l|l|l|}
\hline No. & Perusahaan & $\begin{array}{l}\text { Tahun } \\
\text { Berdiri }\end{array}$ & Komoditas & Pasar yang Dituju \\
\hline 1. & $\begin{array}{l}\text { Bina Sarana } \\
\text { Bakti }\end{array}$ & 1994 & $\begin{array}{l}\text { Sayuran lokal seperti: } \\
\text { wortel, timun, oyong, } \\
\text { buncis, kacang merah, } \\
\text { bawang daun dll }\end{array}$ & $\begin{array}{l}\text { Rumah Sakit, Gereja } \\
\text { dan orang-orang yang } \\
\text { mengkonsumsi sayuran } \\
\text { organic. }\end{array}$ \\
\hline 2. & $\begin{array}{l}\text { Saung } \\
\text { Mirwan }\end{array}$ & 1984 & $\begin{array}{l}\text { Bunga potong, } \\
\text { Edamame, okra, zukini, } \\
\text { nazubi dll }\end{array}$ & $\begin{array}{l}\text { Supermarket dan } \\
\text { restaurant. }\end{array}$ \\
\hline 3. & Joro & 1992 & $\begin{array}{l}\text { Perusahaan penyedia } \\
\text { sarana produksi } \\
\text { pertanian }\end{array}$ & $\begin{array}{l}\text { Perusahaan dan } \\
\text { komunitas sekitar. }\end{array}$ \\
\hline
\end{tabular}

Keterangan: Disarikan dari berbagai sumber.

Perusahaan-perusahaan tersebut masih tetap eksis sampai saat ini. Kehadiran perusahaan agribisnis sangat berpengaruh terhadap perkembangan komoditas sayuran di Kabupaten Bogor. Mutu produk dari komoditas yang diusahakan sangat diperhatikan setelah masuknya perusahaan agribisnis tersebut.

Masing-masing perusahaan tersebut punya kekhasan dalam kegiatan usahanya. Perusahaan Bina Sarana Bakti (BSB) merupakan perusahaan yang membudidayakan sayuran lokal dengan teknik pertanian organik. PT. Saung Mirwan (SM) memperkenalkan komoditas baru seperti, okra (Abelmoschus esculantus), edamame (Glycine max L.), zuchini (Cucumis satious), nazubi, buncis mini, cisito, dll. PT Joro merupakan perusahaan yang menyediakan sarana produksi pertanian, khususnya untuk Green House.

Cianjur merupakan sentra produksi sayuran di Jawa Barat. Dari total penduduk Kabupaten Cianjur yang bekerja di sektor pertanian sebesar 60,6\%. Produk unggulan Kabupaten Cianjur adalah sawi, wortel, bawang daun, tomat. 
Saat ini petani sudah membudidayakan komoditas eksklusif diantaranya tangho, horinso, dan brokoli. Dua perusahaan agribisnis di Kabupaten Cianjur yang bermitra dengan petani dapat dilihat pada Tabel 6 .

Tabel 6 Perusahaan Agribisnis di Kabupaten Cianjur

\begin{tabular}{|l|l|l|l|l|}
\hline No. & \multicolumn{1}{|c|}{ Perusahaan } & $\begin{array}{c}\text { Tahun } \\
\text { Berdiri }\end{array}$ & \multicolumn{1}{|c|}{ Komoditas } & \multicolumn{1}{|c|}{$\begin{array}{c}\text { Pasar yang } \\
\text { dituju }\end{array}$} \\
\hline 1. & Pacet Segar & 1975 & $\begin{array}{l}\text { Bayam, kangkung, buncis mini, } \\
\text { wortel, selada keriting, kyuri, } \\
\text { zukini, okra }\end{array}$ & $\begin{array}{l}\text { Supermarket, } \\
\text { restoran, hotel, } \\
\text { pasar lokal }\end{array}$ \\
\hline 2. & Kem Farm & 1987 & $\begin{array}{l}\text { Paprika, zukini, selada, brokoli, } \\
\text { tomat, wortel, kol, kentang }\end{array}$ & $\begin{array}{l}\text { Supermarket } \\
\text { dan restoran }\end{array}$ \\
\hline
\end{tabular}

Keterangan: Disarikan dari berbagai sumber.

Komoditas unggulan untuk sayuran di Kabupaten Cianjur sawi, wortel, bawang daun, tomat. Kehadiran perusahaan-perusahaan Agribisnis di Kabupaten Cianjur sangat bermanfaat bagi kemajuan usaha tani sayuran di daerah tersebut.

Perusahaan yang ada di daerah tersebut sebagian menjalin kemitraan dengan petani dan pedagang pengumpul. Dengan kerjasama tersebut petani menanam komoditas yang dibutuhkan perusahaan mitranya, dengan komoditas yang tergolong masih baru, seperti tangho, brokoli, harinso, kyuri, nazubi dan lainlain.

Karena komoditas ini masih baru dan kurangnya informasi yang diterima petani banyak petani yang mengalami kegagalan tetapi ada juga yang bertahan dan berhasil mengembangkannya sampai sekarang. Petani yang tetap bertahan menanam produk-produk eksklusif adalah petani yang memiliki kepastian pasar biasanya bermitra dengan pedagang pengumpul yang bermitra dengan perusahaan.

Kabupaten Bandung merupakan wilayah yang paling besar menghasilkan hampir semua jenis sayuran dan penyumbang terbesar terhadap total produksi sayuran di Jawa Barat. Sebagian besar penduduknya $(24.37 \%)$ bermata pencaharian sebagai petani, dengan wilayah yang sangat potensial untuk pengembangan hortikultura khususnya tanaman sayuran.

Bisnis sayuran di Kabupaten Bandung mulai ditekuni oleh petani setelah masuknya perusahaan-perusahaan suplier sayuran yang membantu petani dalam pemasaran produknya. Perusahaan-perusahaan agribisnis di Kabupaten Bandung yang bermitra dengan petani dapat dilihat pada Tabel 7.

Banyaknya perusahaan suplier di Kabupaten Bandung sangat menguntungkan bagi petani dalam hal pemasaran, karena ada kemudahan dalam pemasaran maka banyak petani yang beralih dari tanaman pangan ke tanaman sayuran. 
Jenis sayuran yang dibudidayakan petani juga mengalami perkembangan. Komoditas yang dibudidayakan petani tidak lagi hanya tanaman sayuran lokal tetapi tanaman yang mempunyai nilai bisnis yang tinggi. Petani mulai menanam tanaman-tanaman eksklusif sesuai dengan permintaan pasar.

Tabel 7 Perusahaan Agribisnis di Kabupaten Bandung

\begin{tabular}{|l|l|l|l|l|}
\hline No. & $\begin{array}{l}\text { Nama } \\
\text { Perusahaan }\end{array}$ & $\begin{array}{l}\text { Tahun } \\
\text { Berdiri }\end{array}$ & Komoditas & Pasar yang Dituju \\
\hline 1. & PT Joro & 1992 & $\begin{array}{l}\text { Penyedia sarana produksi } \\
\text { tanaman hortikultura, Penyedia } \\
\text { jasa pelatihan budidaya tanaman } \\
\text { hortikultura }\end{array}$ & $\begin{array}{l}\text { Supermarket dan } \\
\text { petani }\end{array}$ \\
\hline 2. & $\begin{array}{l}\text { Koperasi Mitra } \\
\text { Suka Maju }\end{array}$ & 1999 & Paprika & $\begin{array}{l}\text { Supermarket dan } \\
\text { restoran, ekspor }\end{array}$ \\
\hline 3. & $\begin{array}{l}\text { Pondok } \\
\text { Pesantren Al } \\
\text { I'tiffaq }\end{array}$ & $\begin{array}{l}\text { Sayuran lokal seperti: wortel, } \\
\text { kubis, kentang, timun, buncis, } \\
\text { kacang merah, bawang daun dll }\end{array}$ & $\begin{array}{l}\text { Supermarket dan } \\
\text { restoran, pasar } \\
\text { lokal }\end{array}$ \\
\hline
\end{tabular}

Keterangan: Disarikan dari berbagai sumber.

Komoditas baru yang dikembangkan petani diantarannya adalah, paprika (Capsicum annum L.), baby corn (Zea mays), baby kaelan (), baby lettuce, baby kyuri, beetroot, brokoli (Brasica oleracea), buncis (Phaseolus vulgaris L), chuciwis, daun gingseng, dan kabocha. Dengan bertambahnya jenis komoditas baru ini sangat berpengaruh terhadap jumlah produksi tanaman sayuran. Meskipun kubis, tomat dan kentang dalam kurun waktu sepuluh tahun terakhir ini masih menjadi tanaman yang menjadi primadona petani tetapi produksinya mengalami penurunan sebesar $10 \%$.

Teknik budidaya untuk komoditas baru tersebut lebih rumit, dan membutuhkan modal yang besar. Bimbingan teknis dan kredit saprodi dari perusahaan agribisnis tersebut menjadi hal yang menentukan keberhasilan petani dalam berproduksi. Keberadaan PT Joro dalam sejarah pengembangan agribisnis sangat penting terutama untuk sayuran yang membutuhkan biaya tinggi seperti paprika. Keberhasilan para petani yang tergabung dalam Koperasi Mitra Sukamaju adalah salah satu bukti tentang pentingnya peran perusahaan dalam membantu petani mengembangkan bisnis sayuran.

Kabupaten Garut merupakan salah satu kabupaten penyumbang terbesar untuk sektor pertanian Propinsi Jawa Barat. Selama kurun waktu sepuluh tahun dari tahun 1993 sampai 2003 penduduk yang bekerja di sektor pertanian mengalami penurunan dari 59.03\% (tahun 1993) menjadi $46.30 \%$ pada tahun 2003.

Sejak tahun 1970 telah ada satu perusahaan agribisnis yang mengembangkan kubis dan kentang, namun bisnis sayuran di Kabupaten Garut mulai berkembang sejak tahun 1994. Pada tahun tersebut PT Sartindo Utama 
melakukan budidaya, pengolahan dan memasarkannya timun Jepang ke pasar lokal dan ke Jepang

Perusahaan tersebut melakukan inovasi dalam bisnis sayuran baik dari jenis produk maupun dari pemasarannya, pada saat petani lain menjalankan usaha secara tradional dengan komoditas dan pasar lokal. Komoditas unggulan Kabupaten Garut antara lain Kentang (Solanum tuberosum), cabe (Capsicum annum L.), kubis (Brassica oleracea), tomat (Lycopersion esculentum Miller) dan wortel (Daucus carota L.). Dari sejumlah perusahan agribisnis sayuran yang mempengaruhi perkembangan bisnis sayuran di Kabupaten Garut hanya satu perusahaan saja yang bermitra dengan petani, yaitu PT Saung Mirwan.

PT Saung Mirwan mulai mengadakan kemitraan dengan petani pada tahun 1998, tetapi kemitraan ini sempat terhenti selama satu tahun yaitu tahun 1999. Pada tahun 2000 PT Saung Miwan kembali melanjutkan kemitraannya sampai sekarang. Melalui PT Saung Mirwan petani yang menjadi mitranya belajar menanam tanaman yang baru dan mempunyai nilai jual yang lebih tinggi. Tanaman-tanaman jenis baru ini sangat diminati petani di Kabupaten Garut, karena ada kepastian pasar dan harganya relatif lebih tinggi. Meskipun tanaman kentang tetap menempati urutan pertama dari daftar sayuran yang diproduksi Kabupaten Garut tetapi jumlah produksi mengalami penurunan sebesar 76.6 persen.

\subsection{Alasan Bermitra}

Adanya jaminan pemasaran merupakan alasan utama petani untuk bermitra. Beberapa alasan lainnya petani terlibat dalam pola kemitraan disajikan pada Tabel 8.

Tabel 8 Persentase Petani menurut Alasan Bermitra $(\mathrm{N}=216)$

\begin{tabular}{|l|l|c|c|}
\hline No. & \multicolumn{1}{|c|}{ Alasan Bermitra } & Jumlah & Persen \\
\hline 1. & Pemasaran Terjamin & 202 & 93,4 \\
\hline 2. & Tersedia Bibit/benih & 90 & 41,8 \\
\hline 3. & Produktivitas lebih tinggi & 72 & 33,5 \\
\hline 4. & Ada kegiatan pendampingan & 70 & 32,5 \\
\hline 5. & Meniru petani lain & 70 & 32,5 \\
\hline 6. & Tersedia Pupuk & 59 & 27,4 \\
\hline 7. & Tersedia Pestisida & 58 & 27,0 \\
\hline 8. & Jenis tanaman tahan hama penyakit & 24 & 11,3 \\
\hline 9. & Diajak petugas pendamping & 22 & 10,4 \\
\hline
\end{tabular}

Catatan: Satu petani bisa lebih dari satu alasan

Pemasaran Terjamin. Sebagian besar $(93,4 \%)$ petani menyatakan alasan bermitra karena pemasaran terjamin. Petani melakukan proses produksi secara 
optimal, dengan harapan seluruh hasilnya dapat dipasarkan dengan harga yang memadai.

Tersedia Bibit/benih. Alasan kedua adalah karena tersedia benih/bibit. Petani tidak perlu membeli ke pasar atau kios saprodi karena disediakan pinjaman benih/bibit. Dalam beberapa kasus petani kesulitan mencari benih/bibit satu jenis komoditas sayuran. Benih sayuran tertentu misalnya Brokoli sering tidak tersedia. Dengan bermitra 41,8 persen petani menyatakan termotivasi karena tersedia benih/bibit.

Produktivitas lebih tinggi. Beberapa jenis sayuran yang dimitrakan mempunyai produktivitas yang lebih tinggi dibanding sayuran yang tidak dimitrakan. Produktivitas ini diukur dari hasil persatuan luas tertentu per periode waktu tertentu. Beberapa sayuran yang dimitrakan mempunyai harga yang relatif lebih tinggi, dengan umur yang relatif pendek, sehingga lebih menguntungkan. Produktivitas yang tinggi ini juga dibarengi dengan tingkat kerumitan budidaya dan biaya produksi yang relatif tinggi juga, sehingga tidak semua petani mampu. Hal ini terbukti bahwa hanya 33,5 persen petani yang menyatakan bahwa jenis sayuran yang dimitrakan mempunyai produktivitas yang lebih tinggi.

Ada kegiatan pendampingan. Alasan bermitra berikutnya bagi petani adalah adanya kegiatan pendampingan dari petugas dan meniru teman (32,5 persen). Kerumitan dalam prosedur bermitra dan teknik budidaya dimudahkan dengan adanya penyampingan oleh petugas. Kunjungan petugas pendamping ke lahan atau rumah petani merupakan saat-saat yang dimanfaatkan petani untuk mendiskusikan masalah-masalah teknik budidaya, hama dan penyakit, mutu produk, modal usaha, dan lain-lain. Petani juga seringkali berinisiatif sendiri untuk mencari petugas pendamping ke rumahnya atau ke kantor apabila ada hal penting yang harus dibicarakan.

Meniru petani lain. Sebanyak 32,5 persen petani menyatakan bahwa mereka bermitra karena melihat keberhasilan petani lain. Petani belajar dengan mengamati dari teman sesama petani. Petani melihat bagaimana temannya bisa hidup lebih baik setelah ikut pola kemitraan. Hal itu kemudian memotivasi dia untuk mencoba ikut bermitra.

Tersedia pupuk dan pestisida. Petani seringkali tidak punya modal uang yang cukup untuk membeli pupuk dan pestisida, dia hanya punya modal tenaga kerja, dan benih/bibit. Hampir semua jenis sayuran memerlukan pupuk dan pestisida yang cukup untuk dapat mencapai mutu yang baik. Oleh karena itu alasan tersedia pupuk dan pestisida merupakan sumber motivasi untuk bermitra bagi petani yang kurang modal.

Jenis tanaman tahan hama penyakit. Petani berupaya melakukan rotasi tanaman untuk memutus siklus hama penyakit, atau menjaga kesuburan tanah. Jenis tanaman lebih tahan terhadap hama penyakit merupakan salah satu alasan petani melakukan pola kemitraan. Jenis tanaman seringkali merupakan 
tanaman yang sama sekali baru, atau tanaman jenis lama dengan varietas baru yang menurut petani lebih tahan terhadap hama penyakit.

Diajak petugas pendamping. Dalam hal ini petugas pendamping secara periodik melakukan kunjungan ke petani-petani di wilayah kerjanya untuk mencari petani yang mau bermitra, mau menanam jenis tanaman yang dibutuhkan. Sebagian petani tertarik ikut bermitra karena diajak oleh petugas pendamping. Alasan ini biasanya disertai alasan lainnya, tidak semata-mata alasan tunggal, sebab meskipun petani tidak diajak oleh petugas pendamping bisa saja petani menawarkan diri untuk bermitra karena alasan lain yang lebih kuat seperti telah dijelaskan di atas

\subsection{Alasan Berhenti Bermitra}

Beberapa alasan petani bermitra dapat dikategorikan dalam dua kategori besar, yaitu: (1) alasan yang bersumber dari pihak petani atau (2) alasan yang bersumber dari Pihak perusahaan. Tabel 9 menyajikan beberapa alasan berhenti bermitra yang berasal dari pihak petani, perusahaan, koperasi, atau pedagang pengumpul.

Tabel 9 Alasan Berhenti Bermitra

\begin{tabular}{|c|c|}
\hline Alasan Petani & Alasan Perusahaan \\
\hline $\begin{array}{l}\text { 1. Rugi karena panen sedikit, sehingga } \\
\text { pendapatan turun } \\
\text { 2. Gagal panen } \\
\text { 3. Tidak ada lahan karena dijual, batas } \\
\text { sewa tanah habis } \\
\text { 4. Tidak ada modal } \\
\text { 5. Tidak tergarap, sudah sibuk } \\
\text { 6. Ingin mandiri, menjual sendiri di } \\
\text { pasar, karena harga lebih fluktuatif } \\
\text { 7. Ingin menguntungkan } \\
\text { 8. Gantiadi pedagang } \\
\text { 9. Rotasi tanaman } \\
\text { 10. Ingin punya usaha sendiri } \\
\text { 11. Tanaman tidak cocok dengan lahan } \\
\text { 12. Tanah diberakan selama } 3 \text { bulan } \\
\text { 13. Karena lebaran } \\
\text { 14. Pindah mitra }\end{array}$ & 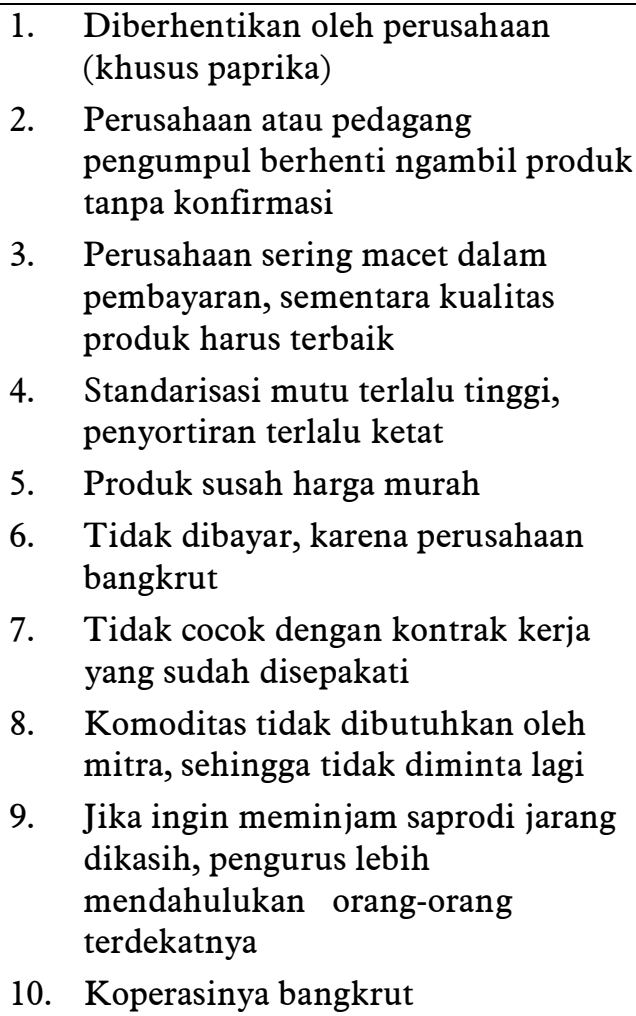 \\
\hline
\end{tabular}


11. Harga tidak memuaskan

12. Tidak ada kesepakatan harga,

13. Tidak disediakan pinjaman uang, atau sarana produksi

14. Bibit tidak tersedia sehingga lahan terbengkalai

Secara umum petani berhenti bermitra karena beberapa alasan, yaitu: karena alasan lahan, kegagalan panen, ada kegiatan lain, ingin punya usaha sendiri, dan tidak punya modal. Alasan yang bersumber dari perusahaan, koperasi atau pedagang pengumpul secara umum adalah: masalah harga dan pembayaran, produk tidak dibutuhkan lagi, standar mutu yang terlalu tinggi atau tidak jelas, dan masalah keuangan lainnya seperti bangkrut atau keterbatasan modal.

\section{Strategi Kemitraan Agribisnis Berkelanjutan}

Penerapan pola kemitraan agribisnis sayuran di Jawa Barat, menemukan beberapa kelemahan dalam praktek yang berakibat pada berhentinya proses kerjasama. Strategi kemitraan yang berupa tahapan-tahapan proses yang dirancang dengan memanfaat kekuatan dan mengurangi kelemahan masingmasing pihak yang bermitra, dalam rangka menjadikan pola kemitraan sebagai strategi peningkatan kapasitas petani kecil secara berkelanjutan.

Dibeberapa lokasi kasus ditemukan kesamaan dalam perkembangan bisnis sayuran, yaitu ditandai dengan perubahan jenis sayuran yang ditanam atau peningkatan mutu dari sayuran lokal. Upaya ini dilakukan agar sayuran yang dihasilkan sesuai dengan permintaan atau kebutuhan konsumen. Kehadiran perusahaan agribisnis sangat bermanfaat bagi petani di sekitar perusahaan. Pendampingan yang dilakukan oleh petugas, bermanfaat bagi peningkatan penggunaan teknologi dan ketrampilan petani dalam budidaya sayuran dalam rangka mencapai mutu produk yang diharapkan. Kehadiran perusahaan agribisnis juga membawa inovasi bagi petani, yaitu komoditas jenis baru, perbaikan mutu produk maupun manajemen usahatani.

\subsection{Mengapa Harus Bermitra ?}

Sebelum menjawab pertanyaan ini, terlebih dahulu harus dipertegas tentang konsep bermitra, atau penerapan pola kemitraan, adalah melakukan proses kerjasama antar pelaku agribisnis dalam berbagai pola, dari yang sangat informal sampai yang formal, dari yang berbentuk kelompok kecil sampai organisasi yang komplek. Beberapa alasan mengapa harus bermitra antar para pelaku agribisnis dijelaskan pada bagian berikut.

(1) Konsekuensi dari Agribisnis di Era Kebutuhan Masyarakat yang Semakin Kompleks. Dalam rangka pengembangan agribisnis, perlu suatu konsep yang 
dapat menggambarkan fungsi-fungsi pengorganisasian kegiatan yang saling kait mengkait antara sub-sub sistem pembentuk sistem agribinis. Kemitraan yang pada intinya adalah proses kerjasama merupakan proses pengorganisasian banyak kegiatan yang saat ini dirasakan sebagai suatu kebutuhan karena karakteristik petani yang semakin kompleks menghadapi kebutuhan masyarakat non petani yang juga semakin banyak dan kompleks. Perlu upayaupaya dari para pelaku agribisnis untuk menghadapi kebutuhan masyarakat non petani akan produk pertanian khususnya sayuran, agar membanjirnya produk sayuran luar negeri dapat dihadapi.

Fungsi-fungsi pengorganisasian kegiatan dalam pola kemitraan merupakan strategi agar seluruh sub sistem agribisnis dapat berjalan, menghasilkan produk dan pelayanan dengan mutu yang lebih baik dibanding jika tidak melalui kemitraan. Mengsinergikan kekuatan antara pelaku dalam satu sub sistem maupun antara sub sistem, sehingga berbagai masalah yang bersumber dari keterbatasan-keterbatasan yang saat ini banyak dialami oleh para petani dapat diatasi.

(2) Spesialisasi Kegiatan untuk Efisiensi. Dengan bermitra, maka akan terjadi pembagian kegiatan dalam sistem agribisnis sesuai dengan kekuatan dan keterbatasan para pelaku. Hal ini dalam jangka panjang akan meningkatkan kemampuan khusus yang berbeda-beda (spesialisasi) sehingga lebih efisien. Kelemahan petani secara umum adalah: teknologi terbatas sehingga bekerja mengikuti musim, lahan terbatas, keahlian terbatas, jaringan pemasaran terbatas, modal terbatas. Kelemahan ini diminimalisir dengan kekuatankekuatan yang dimiliki oleh perusahaan, koperasi, maupun pedagang ngumpul. Kekuatan-kekuatan tersebut antara lain: penggunaan teknologi baik, pengorganisasian kegiatan baik, ada dukungan tenaga kerja sesuai bidangnya, akses terhadap lembaga keuangan, luas dalam jaringan pemasaran.

(3) Kerjasama Pemerintah-Swasta dalam Penyelenggaraan Penyuluhan. Pemerintah mempunyai kewenangan untuk mengatur agar proses penyelenggaraan penyuluhan yang dilakukan oleh para petugas pendamping dari perusahaan, koperasi, maupun oleh pedagang pengumpul dapat berjalan dengan baik, dan sejalan dengan program pemerintah. Pola kemitraan memberikan peluang kerjasama antara petani pengusaha, pedagang, dan pemerintah dalam mengembangkan agribisnis sesuai dengan potensi wilayahnya.

\subsection{Siapa yang Bermitra ?}

Pihak yang bermitra adalah petani, pedagang saprotan, pedagang pengumpul, perusahaan, pedagang di pasar tradisional, supermarket, restoran dengan beragam pola (Lihat Lampiran 1)

\section{Petani dan Perusahaan Besar}

Kasus pola kemitraan yang diterapkan oleh Perusahaan SM, PS, KF, PAI, adalah kasus kemitraan antara petani dan perusahaan agribisnis. Petani melakukan unit produksi sesuai dengan kebutuhan perusahaan, kemudian 
perusahaan memasarkan ke supermarket dan restoran tertentu. Kasus pola kemitraan yang diterapkan oleh Perusahaan JR, adalah kemitraan dalam hal pengadaan sarana produksi dan pembinaan teknis budidaya khususnya untuk sayuran yang ditanam di green house. Petani berinteraksi dengan petugas perusahaan dalam menyelesaikan masalah-masalah yang dihadapi terutama dalam teknis budidaya dan penanganan hama dan penyakit.

\section{Petani dan Pedagang Pengumpul}

Kemitraan petani dengan pedagang pengumpul (istilah lainnya adalah bandar, tengkulak) adalah sudah umum terjadi. Pedagang pengumpul membeli hasil sayuran petani, kemudian dia memasok ke perusahaan agribisnis atau langsung ke supermarket dan restoran. Dengan kemudahan sarana transportasi dan telekomunikasi, para pedagang pengumpul yang biasanya juga merangkap sebagai petani, telah mampu menembus pasar swalayan, restoran besar. Untuk menjamin pasokan sayuran yang kontinyu seorang pedagang pengumpul bisa bermitra dengan para petani di sekitar wilayah tempat tinggalnya atau bahkan harus mengunjungi petani-petani di wilayah lain, atau mencari ke pasar-pasar tradisional untuk mencari sayuran sesuai kebutuhan.

\section{Petani dan Koperasi}

Kasus pola kemitraan yang diterapkan oleh Koperasi KMS merupakan contoh pola kemitraan antara petani dan Koperasi. Para petani yang tinggal di suatu lokasi bersama-sama membentuk koperasi untuk mempermudah dalam memasarkan hasil. Koperasi kemudian memasarkan hasil sayuran para anggotanya ke super market dan restoran besar.

\section{Petani dan Pedagang Pasar Tradisional}

Beberapa petani mengatakan bahwa dia tidak pernah bermitra dengan siapapun, tetapi ia mempunyai pedagang langganan di pasar. Meskipun tidak ada aturan yang mengikat tetapi petani sering bahkan ada yang selalu ke pedagang tersebut. Hubungan pertemanan membuat petani mempunyai memperoleh kemudahan saat menjual hasil panennya, dengan harga sesuai yang berlaku di pasar tersebut.

\subsection{Pola Kemitraan Apa yang Diterapkan ?}

\section{Komponen yang dimitrakan.}

Penerapan pola kemitraan ditujukan selain untuk mengatasi masalah kekurangan modal, lemah teknologi, menjamin pemasaran, sehingga dapat meningkatkan pendapatan petani, juga harus menguntungkan bagi pihak-pihak lain yang bermitra, karena bila tidak maka tidak akan berkelanjutan. Komponen yang dimitraan merupakan bagian dari sub sistem agribisnis mulai 
dari input produksi (benih, pupuk, obat-obatan pengendali hama penyakit, dan alat produksi), proses produksi, pengangkutan, dan penanganan pasca panen (cleaning, packaging, processing), serta pemasaran.

"Mensinergikan kekuatan" untuk mengurangi kelemahan merupakan dasar pertimbangan tentang komponen apa yang akan dimitrakan. Tidak ada satu pola yang dianggap paling benar dan dapat mewakili semua kondisi petani, karena komponen yang dimitrakan tergantung pada kebutuhan dari pihakpihak yang bermitra.

\section{Sumber Motivasi.}

Sumber motivasi penerapan pola kemitraan adalah kebutuhan yang dirasakan oleh pihak-pihak yang ingin bermitra. Bagi petani, sumber motivasi terbesar untuk ikut dalam pola kemitraan adalah karena pemasaran terjamin, kemudian karena tersedia benih/bibit, pupuk atau pestisida, jenis tanaman yang dimitrakan punya produktivitas yang tinggi, ada pendampingan petugas pendamping, dan karena petani lain juga ikut. Apabila komponen yang dimitrakan sesuai dengan kebutuhan usaha, maka itulah sumber motivasinya.

Sumber motivasi ini tidak semata-mata merupakan keuntungan secara ekonomi. Hasil penelitian ini membuktikan bahwa kemudahan dalam pola kerjasama, kemudahan dalam prosedur dan aturan kerjasama, sistem penetapan harga dan pembayaran yang baik, dan kemungkinan petani mencapai standar mutu yang ditetapkan oleh mitranya, merupakan hal -hal positif yang dapat meningkatkan peluang petani untuk bermitra. Bagi petani, petani merasa senang dan bangga bila dapat menghasilkan produk dengan mutu yang baik. Proses ini merupakan proses yang tidak saja pada saat setelah hasil dipanen, tetapi sejak proses produksi. Standar mutu sayuran yang baik meliputi ukuran (size), warna (colour), dan penampilan (appearance). Pengetahuan petani tentang mutu dan bagaimana mencapai mutu tersebut diperoleh petani melalui pola kemitraan.

Bagi pihak yang ingin bermitra dengan petani, sumber motivasinya adalah adanya keberlanjutan usaha yang dikelola. Pasokan bahan baku dari petani secara terus-menerus merupakan dasar kerjasama dalam pola kemitraan. Tanpa adanya bahan baku dari petani pengusaha akan kesulitan memenuhi permintaan konsumen. Sebagai pengusaha pertanian memperoleh keuntungan dari kegiatan agribisnis yang dilakukan adalah tujuan utamanya. Dari penelitian ini terbukti bahwa perusahaan yang semata-mata mencari keuntungan tanpa memperhatikan kebutuhan petani mitranya, akan ditinggalkan oleh petani mitranya. Jadi proses bermitra selain merupakan wadah belajar bagi petani juga bagi perusahaan mitra, yaitu belajar untuk bekerjasama dan saling menguntungkan. 


\section{Apa yang harus dihindarkan ?}

Hasil penelitian menunjukkan bahwa berhentinya proses kerjasama antara para pelaku terjadi pada saat satu pihak merasa diperlakukan tidak adil, dirugikan, dieksploitasi, atau dimanipulasi, oleh pihak lain. Ketidakadilan ini kadangkadang tidak tampak, karena struktur masyarakat yang membuat petani selalu berada pada pihak yang lemah. Misalnya karena petani modalnya kecil maka bagian keuntungannya juga kecil, dan karena perusahaan modal yang dikeluarkan untuk pola kemitraan ini besar maka keuntungan yang diperoleh juga harus besar.

Pandangan tersebut harus diubah, bila kita berfikir bahwa kuatnya suatu kerjasama akan ditentukan oleh pihak yang paling lemah, maka dalam konteks agribisnis, kerjasama yang dapat saling memperkuatlah yang harus dilakukan karena setiap subsistem saling tergantung. Sebuah perusahaan yang konsisten dalam bekerjasama, tidak saja memperhitungkan keuntungan secara ekonomi tetapi juga memperhatikan aspek lain dari kebutuhan petani mitranya, maka dalam jangka panjang akan lebih bertahan karena didukung oleh para petani mitra yang semakin tinggi kinerjanya dan sangat loyal dalam berproduksi sesuai dengan kebutuhan perusahaan mitranya.

\section{Pola Mana yang Paling Menguntungkan Petani ?}

Berdasarkan hasil penelitian ini, maka pola yang disarankan berbeda-beda sesuai dengan karakteristik petaninya. Secara garis besar ada 3 pola yang disarankan, namun pada penerapaknnya di lapangan harus disesuaikan dengan kebutuhan dari pihak-pihak yang bermitra untuk menentukan komponen apa yang dimitrakan.

1. Bagi petani maju, cukup modal dan teknologi: buatlah usaha sendiri, memproduksi dan mengumpulkan produk petani-petani lain, kemudian mencari pasar sendiri.

2. Bagi petani dengan kultur pedesaan dengan semangat gotong royong dan kebersamaan hidup yang kuat, interaksi yang sangat dekat satu dengan yang lain dalam wilayah tertentu, dengan struktur yang tidak terdeferensisai secara tajam: bentuklah kelompok usaha bersama (koperasi misalnya).

3. Bagi petani kecil yang kekurangan modal dan teknologi, interaksi di antara petani kurang, atau tinggal berjauhan, maka bermitralah dengan pedagang pengumpul atau perusahaan yang akan membantu dalam pengadaan modal, pendampingan petugas untuk teknis budidaya, penggunaan teknologi yang lebih baik, dan menjamin pemasaran produk. 


\subsection{Bagaimana Penerapan Pola Kemitraan ?}

Pola kemitraan yang selama ini diterapkan pada hakekatnya ditujukan pada penyelesaian masalah-masalah dalam sistem Agribisnis.

Pengembangan Kelembagaan di Tingkat Lokal. Pola kemitraan diharapkan dapat mendekatkan petani pada berbagai fasilitas utama dan pendukung agribisnis di tingkat lokal, yang sebelumnya tidak dapat diakses oleh petani. Fasilitas tersebut melekat pada pelayanan yang diberikan oleh lembaga penyedia saprotan, lembaga pemasaran, lembaga keuangan, dan lembaga pendukung lainnya lembaga penelitian, dan agroindustri. Selain itu juga perlu dikembangkan kelembagaan di tingkat petani seperti kelompok tani dan koperasi petani.

Beberapa masalah yang sering dihadapi petani antara lain kesulitan dalam membangun kerjasama dengan berbagai instansi pemerintah, misalnya dalam mendapatkan bimbingan dan pelatihan serta akses permodalan. Dengan pola kemitraan dengan pihak perusahaan swasta, koperasi dan pedagang pengumpul diharapkan masalah ini dapat diatasi.

Pengembangan Kelembagaan Petani. Kelembagaan petani baik yang relevan dibahas di sini dapat merupakan kelembagaan ekonomi, kelembagaan pendidikan, maupun kelembagaan kekerabatan. (Koentjaraningrat, 1979). Kelembagaan ekonomi adalah kelembagaan yang berkaitan dengan pekerjaan, proses produksi, mengumpulkan harta, maupun mendistribusikan harta. Kelembagaan yang berkaitan dengan pekerjaan pertanian adalah kelembagaan atas tanah, kelembagaan penyedia sarana produksi, kelembagaan keuangan, kelembagaan hubungan kerja dalam proses produksi dan panen, serta kelembagaan pemasaran.

1. Kelembagaan atas tanah menjadi penting, karena akan berpengaruh terhadap pemenuhan kebutuhan petani akan tanah sebagai faktor utama usahatani. Banyak kasus petani berhenti karena tidak tersedia lahan yang digunakan untuk bertani. Beberapa kasus petani memperoleh hak atas tanah dari pihak instansi tertentu atau dari "orang-orang jakarta" untuk dikelola ditanami dengan sayuran tanpa harus membayar. Beberapa kasus petani tidak memiliki lahan tetapi mereka menyewa, atau bagi hasil dengan pemilik lahan. Petani yang lain memiliki lahan dengan luasan yang bervariasi mulai dari 0,1 Hektar sampai dengan puluhan Hektar. Lemahnya akses petani terhadap lahan akan berpengaruh terhadap apapun inovasi usahatani yang akan diterapkan, oleh karena itu perbaikan terhadap kelembagaan atas tanah ini menjadi penting.

2. Kelembagaan penyuluhan seharusnya terkait dengan kelembagaan pemasaran, kelembagaan keuangan, kelembagaan penyedia saprotan, kelembagaan Litbang dan kelembagaan Agroindustri. Kegiatan pendampingan yang dilakukan oleh perusahaan, koperasi dan pedagang mengumpul, dalam pola kemitraan dapat disebut sebagai kegiatan penyuluhan. Kegiatan 
pendampingan yang dilakukan selain memberikan informasi tentang teknik budidaya dibeberapa kasus juga disertai dengan penyediaan kredit sarana produksi, dan pembinaan manajemen. Kelembagaan penyuluhan yang dilakukan dalam pola kemitraan di lokasi penelitian paling tidak sudah mengupayakan aksesibilitas petani terhadap pemasaran dan saprotan. Beberapa perusahaan seperti PT SM dan PT JR bahkan sudah mempunyai bagian atau devisi di perusahaanya yang menyiapkan saprotan sendiri terutama untuk memproduksi benih dan pupuk.

Untuk komoditas yang bernilai ekonomi tinggi seperti sayuran, dengan siklus tanam dan perputaran modal yang cepat, permintaan konsumen yang cepat berubah, serta teknologi yang digunakan relatif tinggi dibandingkan tanaman padi maka peranan swasta diperlukan. Perusahaan swasta yang melakukan praktek budidaya dan pemasaran sayuran bernilai ekonomi tinggi terbukti efektif dalam melakukan kegiatan pendampingan, karena kegiatan produksi terhadap satu jenis sayuran tertentu selalu dikaitkan dengan kebutuhan pasar.

Prinsip-prinsip Bermitra. Beberapa prinsip ini ditemukan di lokasi penelitian, baik yang berasal dari pihak petani, pedagang pengumpul, pengurus koperasi maupun dari pihak perusahaan. Prinsip-prinsip tersebut adalah:

(1) Equality, prinsip kesetaraan dalam pengambilan keputusan. Perusahaan sangat tergantung dengan petani, perusahaan tidak dapat hidup tanpa petani, oleh karena itu petani adalah mitra bisnis perusahaan.

(2) Jangan mengecewakan partner. Saling mengerti. Yang penting keinginan petani terpenuhi: " produk dibeli, harga memadai",

(3) Win-win solution, agar kemitraan berlangsung jangka panjang,

(4) Menjaga nama baik, perselisihan antara petani, suplier dan perusahaan dianggap mencemarkan nama baik perusahaan,

(5) Pelayanan yang baik dari perusahaan melalui petugas lapangan, dan staf lainnya,

(6) Komitmen kedua belah pihak, tanpa pemaksaan, saling menilai dan mengingatkan

Hak dan Kewajiban pelaku pola kemitraan disepakati bersama oleh masingmasing pelaku. Beberapa yang berhasil diidentifikasi dalam penelitian ini adalah:

(1) Kewajiban perusahaan, koperasi, dan pedagang pengumpul terdiri dari: (a) membuat rencana tanam petani mitra, (b) melakukan kegiatan pendampingan, (c) membantu menyediakan sarana produksi yang dibutuhkan, (d) harga disepakati kedua belah pihak, (e) semua produk yang memenuhi standar kualitas harus ditampung/dibeli.

(2) Kewajiban petani meliputi: (a) menanam sayuran sesuai dengan program tanam (jenis tanaman ditetapkan), (b) mengikuti dan melaksanakan saran-saran petugas pendampingan, (c) menjual seluruh hasil panen yang 
memenuhi standar kualitas, sesuai dengan kesepakatan harga (d) pinjaman sarana produksi dikembalikan bersamaan dengan hasil panen

Dukungan Kebijakan Pemerintah. Setiap upaya-upaya dalam program pembangunan harus sejalan bahkan mendapat dukungan dari pemerintah melalui kebijakan pemerintah baik ditingkat pusat maupun di tingkat lokal. Sebab bila tidak, upaya tersebut tidak akan berkelanjutan karena masalahmasalah kebijakan.

Beberapa masalah misalnya (1) Tidak adanya kebijakan dan bantuan pemerintah terhadap komoditas hortikultura khususnya paprika, merupakan ancaman bagi perusahan karena perolehan benih dan pupuk didapat dengan cara import; (2) Kebijakan pemerintah luar negeri yaitu adanya larangan eksport terhadap komoditas agribisnis, salah satunya paprika. Hal ini akan mempengaruhi perkembangan bisnis pengusaha paprika di Indonesia.; (3) Produk yang dihasilkan koperasi (paprika) merupakan pelengkap bagi produk lain sehingga biasanya dikonsumsi dalam jumlah terbatas. Dengan demikian kekuatan tawar menawar harga sangat kuat berada pada pihak pelanggan (konsumen)

\section{Kesimpulan dan Saran}

\subsection{Kesimpulan}

1. Penerapan kemitraan agribisnis merupakan hal yang penting dalam rangka mencapai mutu produk sesuai kebutuhan konsumen, spesialisasi kegiatan untuk efisiensi, dan wadah kerjasama pemerintah dan swasta dalam penyelenggaraan penyuluhan pertanian.

2. Pola yang diterapkan tergantung pada kebutuhan dan kemampuan masing-masing pelaku, untuk menentukan komponen yang akan dimitrakan. Sumber motivasinya tidak semata-mata keuntungan ekonomi tetapi juga keberlanjutan usaha.

3. Equality, prinsip kesetaraan (partner) dalam pengambilan keputusan, dan Win-win solution, transparansi merupakan prinsip yang harus diterapkan. Perlakuan tidak adil, merugikan pihak lain, ekspolitasi dan manipulasi adalah hal yang harus dihindarkan

4. Pengembangan kelembagaan di tingkat lokal terutama kelembagaan atas tanah dan kelembagaan penyuluhan merupakan hal yang harus dilakukan sejalan dengan penerapan pola kemitraan.

\subsection{Saran}

\section{Untuk Pemerintah}

1. Konsep kemitraan agribisnis yang harus diperluas bahwa setiap bentuk kerjasama merupakan proses bermitra tanpa harus mencakup seluruh 
aspek agribinsis, sesuai dengan kondisi di lapangan seperti kendalakendala yang berasal dari petani, pengusaha dan sarana serta pasar.

2. Kemitraan yang ideal masih dalam proses, yang tidak mungkin proses tersebut semata-mata diserahkan pada swasta dan petani. Campur tangan pemerintah dalam membuat kebijakan, memperkuat kelembagaan di tingkat lokal yang kondusif untuk mencapai pola kemitraan yang ideal sangat diperlukan,

3. Pedoman Kemitraan Agribisnis yang diterbitkan oleh Departemen Pertanian tahun 2003, mensyaratkan bahwa petani atau kelompok tani yang disarankan ikut dalam pola kemitraan adalah yang sudah dibina oleh pemerintah. Dalam penelitian ini ditemukan bahwa penyuluh pemerintah tidak tersedia di hampir seluruh lokasi petani, sehingga syarat tersebut kurang relevan. Petani generasi muda yang baru memasuki dunia pertanian, biasanya mereka mencari informasi kepada sumber informasi yang ada di sekitarnya, yaitu petugas perusahaan, koperasi atau petani senior yang biasanya juga sebagai pedagang pengumpul.

4. Kebijakan pemerintah di tingkat lokal dalam hal peningkatan ketersediaan sarana transportasi dan telekomunikasi adalah dua hal utama yang mendesak untuk dilakukan dalam rangka mempercepat proses pengembangan agribinis melalui pola kemitraan.

\section{Untuk Pihak-pihak yang akan bermitra dengan petani}

1. Pengurangan terhadap tingkat kerumitan proses bermitra akan mendorong petani ikut dalam pola kemitraan yang ditawarkan. Kejelasan dalam penetapan standar mutu, proses pembayaran yang tanpa masalah, komunikasi yang baik dalam proses kerjasama akan mendukung keberlanjutan pola kemitraan yang dibangun. 


\section{Daftar Pustaka}

BPS Propinsi Jawa Barat. 1993. Jawa Barat dalam Angka 1993. Bandung: BPS Propinsi Jawa Barat.

BPS Propinsi Jawa Barat. 2003. Jawa Barat dalam Angka 2003. Bandung: BPS Propinsi Jawa Barat.

Cresswell, John W. 1994. Research Design: Qualitative and Quantitatif Approaches. Sage Publications, Inc.

Departemen Pertanian. 2003. Pedoman Kemitraan Usaha Agribisnis. Direktorat Pengembangan Usaha.

Rakhmat, Jalaludin. 2001. Psikologi Komunikasi. PT Remaja Rosdakarya. Bandung.

Rogers, E. M. 1995. Diffusion of innovations. Free Press. 4th ed. New York.

Setiawan, Ade Iwan. 1995. Sayuran dataran Tinggi. Budidaya dan Pengaturan Panen. Jakarta: PS. Penebar Swadaya.

Sitorus, Edward. 1994. Makalah Pembahas dalam PIR Perkebunan. Kemitraan Usaha Besar dengan Petani dalam Agribisnis Perkebunan. hal 95103.Yayasan Agrimedia. Jakarta

Soekartawi, 1988. Prinsip Dasar Komunikasi Pertanian. UI Press. Jakarta

Suwarsono dan Alvin.Y. So, 2000. Perubahan Sosial dan Pembangunan. LP3ES. Jakarta

Warsidi . 2003. Sikap terhadap pola kemitraan : Agribisnis Sistem Bagi Hasil dalam Argrimedia (bulan Maret 2003) Direktorat Jendral BPPHP Bina Pengolahan dan Pemasaran Hasil Pertanian.

Yayasan Agrimedia, 1994. Pir Perkebunan. Kemitraan Usaha Besar dengan Petani dalam Agribisnis Perkebunan. Prosiding Seminar. Jakarta. 
Lampiran 1 Beberapa Pola Kemitraan di Lokasi Penelitian

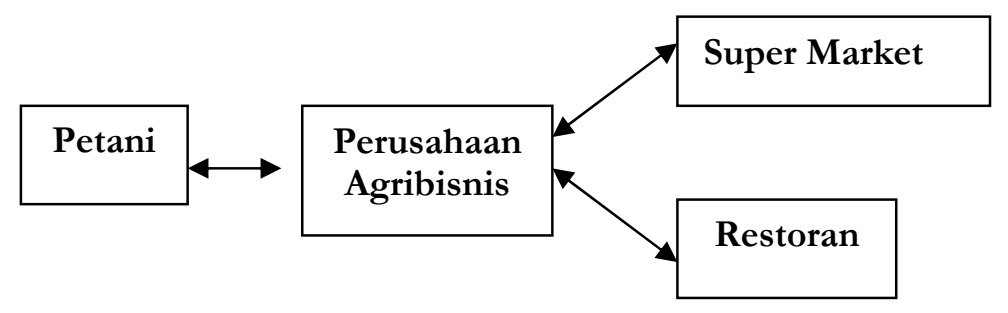

Gambar 1. Pola Kemitraan Petani dan Perusahaan Besar

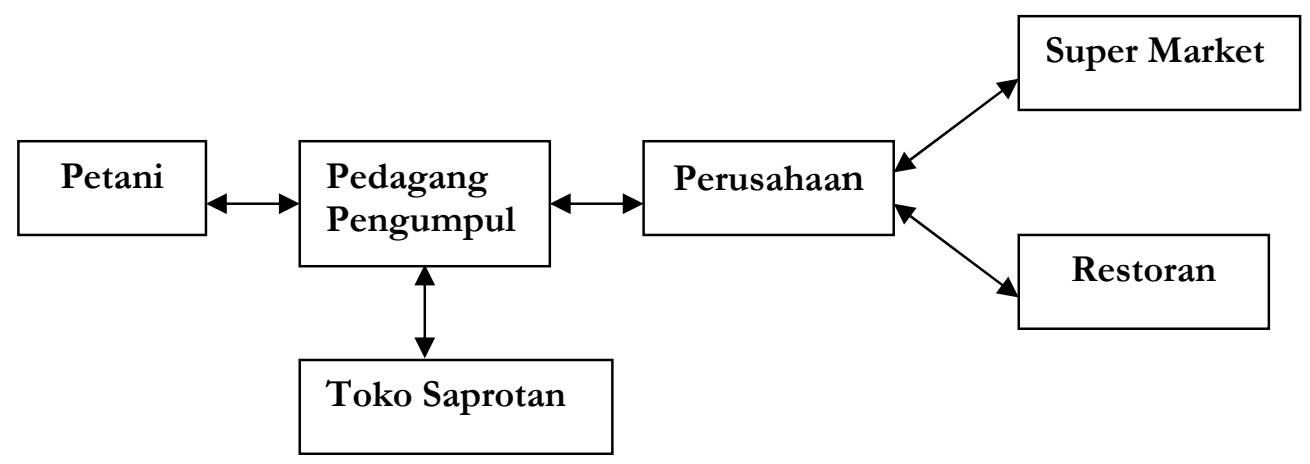

Gambar 2a. Pola Kemitraan Petani dan Pedagang Pengumpul

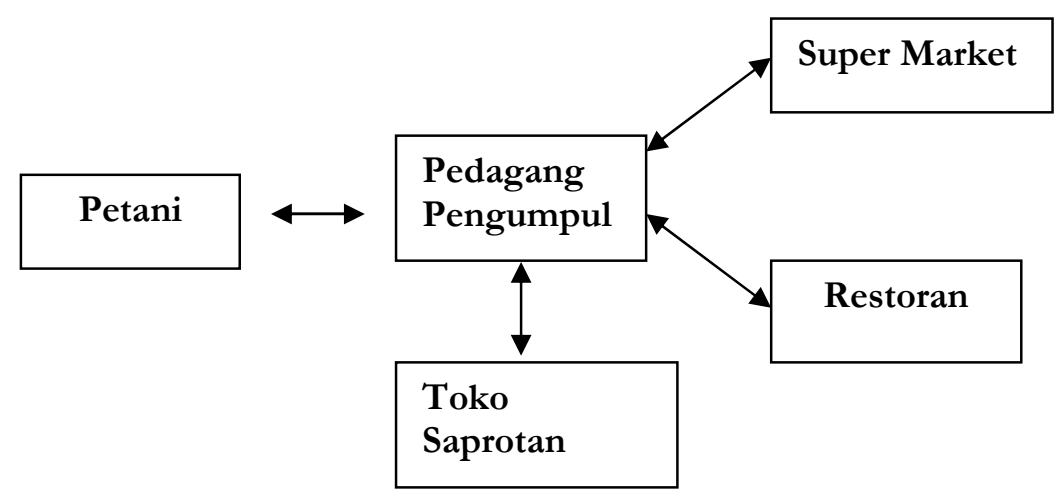

Gambar 2b. Pola Kemitraan Petani dan Pedagang Pengumpul 


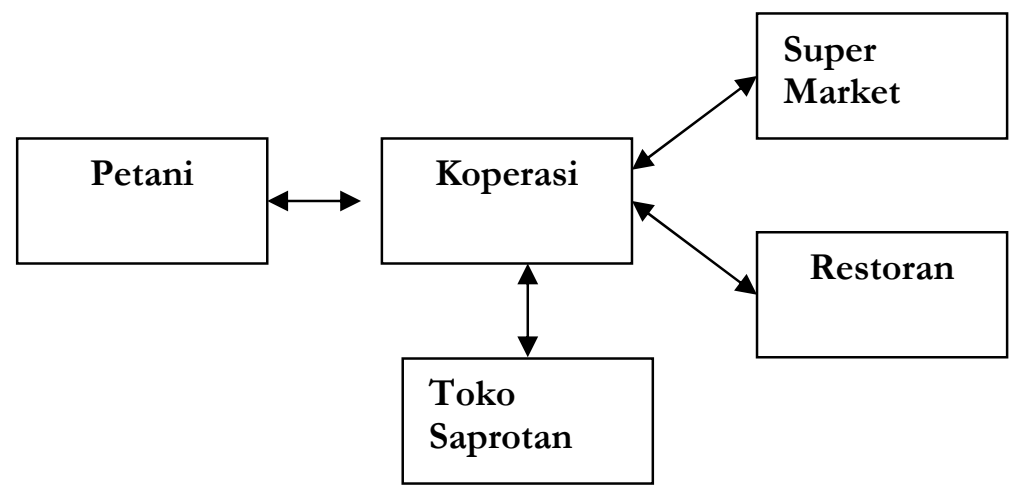

Gambar 3. Pola Kemitraan Petani dan Koperasi 